\title{
Cell-Phone-Only Voters in the 2008 Exit Poll and Implications for Future Non-Coverage Bias
}

\author{
Michael Mokrzycki, Independent Consultant \\ Scott Keeter, Pew Research Center \\ Courtney Kennedy, University of Michigan and The Everett Group
}

\begin{abstract}
National pre-election polls again performed well in 2008, although evidence began to emerge of minor but consistent non-coverage bias if samples excluded cell phones. As in 2004, the National Election Pool's national exit poll in 2008 provided an opportunity to reach Election Day voters regardless of telephone status. The exit poll found a sharp increase in cell-only incidence, comparable to trends in government surveys, with cell-only status approaching the norm for voters under age 30. But the growth rate of cell-only adoption and difference in presidential preference were even greater among voters age 30 and up, suggesting that typical post-stratification weighting adjustments for age may be less likely to mitigate non-coverage bias in future landline-only random digit dial surveys.
\end{abstract}

\section{Introduction}

Since early this decade the survey research profession has studied extensively whether landline random digit dial (RDD) samples may suffer non-coverage bias by omitting people who only have cellular phones (see e.g. AAPOR Cell Phone Task Force 2008). Until 2008 empirical evidence reassured researchers the impact was minimal. While the number of cell-phone-only Americans grew steadily, it remained a small fraction of the general population. Certain subgroups were much more likely to be cell-only (most notably younger people) but differences on demographic and attitudinal measures were small between them and their cohorts who still had landlines. Studies in 2006 found typical post-stratification weighting techniques in landline RDD samples produced survey estimates that hardly differed nominally, much less to a statistically significant degree, from blended landline and cell phone samples (Keeter et al 2007), just as cell-only and landline-reachable voters differed little in the 2004 Election Day exit poll (Keeter 2006).

By the middle of 2008, dual-frame telephone studies began to suggest this situation was changing. For example, in September 2008 the Pew Research Center discerned a pattern in three of its national dual-frame telephone polls on preference in the presidential race: Including a sample of cell phone interviews consistently produced a 2- to 3-point shift in the margin toward Democrat Barack Obama and away from Republican John McCain (Keeter, Dimock and Christian 2008a). Other survey firms found directionally similar results (Benford et al 2009, Langer et al 2009) although shy of statistical significance; a later Pew analysis of combined data from its six pre-election polls from September through the weekend before the election found a statistically significant but small, 2.4-percentage point decrease in Obama's lead when cell phone interviews were excluded (Keeter, Dimock and Christian 2008b). Meanwhile, substitution of wireless for landline telephone service increased unrelentingly - by the second half of 2008, 
fully one in five U.S. households were cell-only, according to the in-person National Health Interview Survey (Blumberg and Luke 2009). Concern about non-coverage and potential bias prompted a number of national pollsters to include cell phone samples in their surveys by the fall of 2008. ${ }^{1}$

Fortunately, final pre-election polling in 2008 was generally accurate, with surveys that excluded cell phones doing about as well as those that included them. Despite the sizeable coverage gap, weighting adjustments still corrected for the growing bias. But new evidence indicates that this fortunate situation is not likely to last indefinitely.

In the November election itself, exit polls - conducted mostly in person outside voting places offered an opportunity to reach a sample of all Election Day voters regardless of their telephone status. As in 2004, the news media consortium that commissions the exit polls included a question on the 2008 national exit poll that allows analysis of attitudinal as well as demographic differences between voters who only have cell phones and those who have landline service. The sharp increase in the incidence of cell-only Election Day voters - from 7\% in 2004 to 20\% in 2008 - enhances the statistical power of the latest subgroup analysis (with nearly 1,500 cell-only respondents). Here we report these results as well as a meta-analysis of dual vs. single-frame telephone polls before the 2008 election, and we attempt to draw implications for future telephone surveys that exclude cell-only respondents.

\section{Research Design}

In the U.S. general elections of 2004 and 2008, the National Election Pool (NEP) - ABC, The Associated Press, CBS, CNN, FOX and NBC - commissioned surveys of voters in all 50 states and the District of Columbia from Edison Media Research and Mitofsky International. In addition, a national survey was conducted. Interviews predominantly were conducted in person on Election Day in a probability sample stratified by geography and past vote. (See National Election Pool 2005 documentation for further detail; sampling and interviewing procedures were not substantively changed for 2008. $)^{2}$

\footnotetext{
${ }^{1}$ Potential non-coverage bias also continued to elicit considerable attention from news reporters and commentators. A search of the keyword combination of "cell phones," "pollsters" and "polls" in the Nexis database for the four weeks before the 2008 election yielded 160 stories in major newspapers, news magazines or broadcast media. The same search of Factiva for the comparable time period in 2004 found 150 stories (Keeter 2006). In both cases very tight search criteria likely produced conservative estimates, and the search parameters excluded blogs.

${ }^{2}$ The completion rate for the Election Day national exit poll was $43.1 \%$. This rate is the number of voters who completed the survey out of the total number selected to take the survey; exit poll interviewers tally the numbers of those who refuse to cooperate or who should be selected according to the in-precinct sampling interval but the interviewer misses. AAPOR Standard Definitions do not define how to calculate response rates for in-person exit polling, only for in-person surveys of households.
} 
In recent years, voters in many states increasingly have cast ballots early or absentee before Election Day. By November 2008 nearly a third of all votes (32.7\%) were cast before Election Day, up from less than a quarter (22.5\%) in 2004 (Associated Press 2009). To cover early voters, in recent years the in-precinct "exit" polls - which interview voters as they exit the voting booth - have been supplemented in numerous states and nationally by telephone surveys conducted the week before the election. Note that all analysis herein is based solely on voters who cast ballots on Election Day in the national sample of 300 precincts, as the 2008 NEP telephone surveys - in 18 states plus a national phone sample - only covered households with landline phones. Also, an analysis of possible effects of excluding cell-only voters from the NEP early voter telephone samples is beyond the scope of this paper; that non-coverage has no bearing on the population being studied here, Election Day voters.

Election Day respondents completed the exit poll using a self-administered paper-and-pencil instrument. There were four versions of the national exit poll questionnaire, two of which included this question: ${ }^{3}$

\section{$[A B]$ What type of telephone service is there in your home that you could use or be reached on? (CHECK ONLY ONE) \\ $1 \square$ Both regular land-line and cell phone service \\ $2 \square$ Only regular land-line phone service \\ $3 \square$ Only cell phone service \\ $4 \square$ No telephone service at home}

Data are not available on certain variables such as marital status and religious affiliation which were not included on the same instrument as the telephone status question.

\section{III.Results}

\section{Incidence of cell-phone-only voters overall}

Table 1 presents the distribution of voters by telephone status in the 2004 and 2008 national exit polls. The proportion of Election Day voters who live in wireless-only households practically tripled over four years, to $20.4 \%$. Another $4.3 \%$ of households had no telephone service at all, indicating that pre-election polls using only landline samples failed to cover about $25 \%$ of the Election Day electorate. Recent research on list-assisted RDD designs, however, suggest that actual non-coverage rates for both landline RDD and dual-frame RDD are even higher than that (Fahimi, Kulp, Brick 2008).

\footnotetext{
${ }^{3}$ There were three minor differences in the presentation of the question in 2004: The words "in your home” were underlined; the parenthetical "Check only one" instruction was not capitalized; and in the second response code there was a comma after the word "regular."
} 


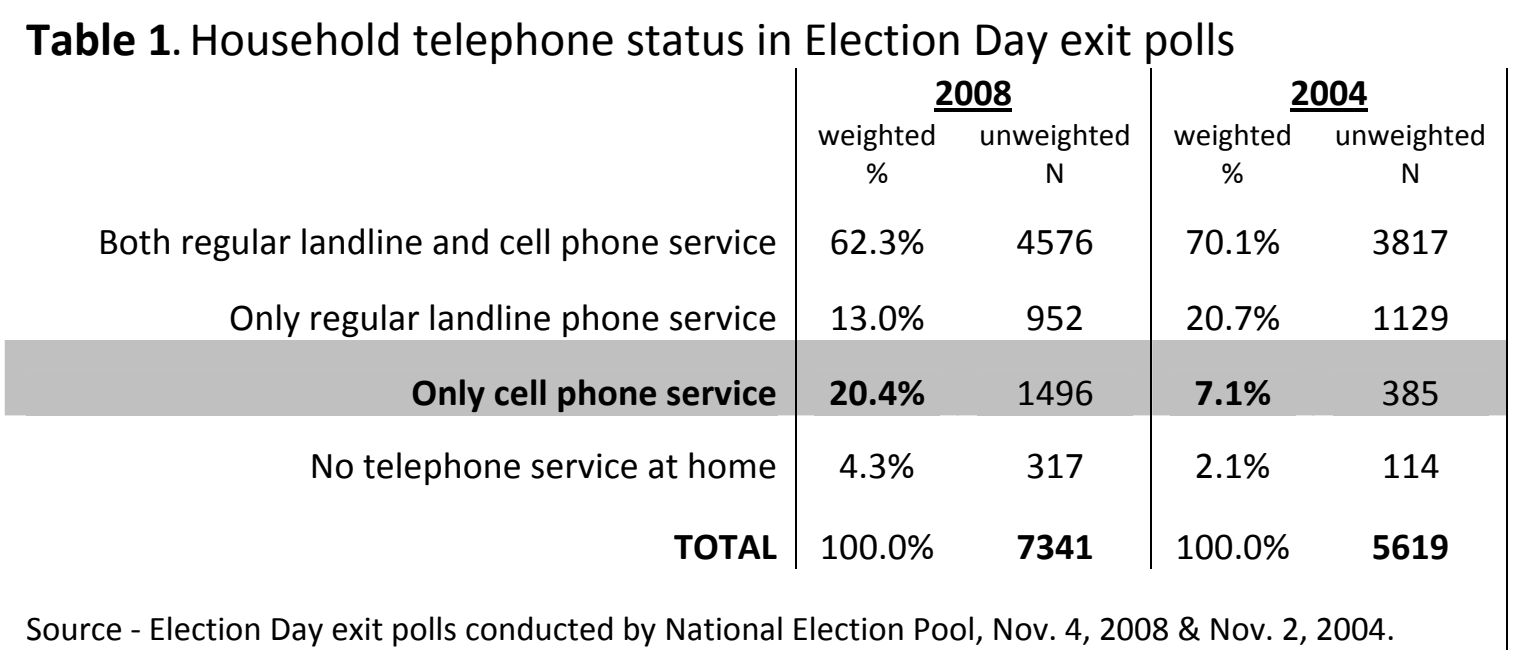

\section{Vote for president by telephone status among Election Day voters}

As relevant as the rate of cell-only status is the degree to which cell-only voters differ from those reachable by landline. Table 2 shows how Election Day voters cast their ballots for president in 2004 and 2008 by telephone status. Cell-only voters clearly were a strong group for the Democratic candidates in both years, while Republicans fared best among Election Day voters with both regular landline service and cell phones in their household.

Table 2. Presidential vote by household telephone status in Election Day exit polls

\begin{tabular}{|c|c|c|c|c|}
\hline & \multicolumn{2}{|c|}{$\underline{2008}$} & \multicolumn{2}{|c|}{2004} \\
\hline & Obama & McCain & Kerry & Bush \\
\hline ACTUAL POPULAR VOTE (Election Day + early) & $52.9 \%$ & $45.7 \%$ & $48.3 \%$ & $50.7 \%$ \\
\hline Both regular landline and cell phone service & $49.2 \%$ & $49.2 \%$ & $46.5 \%$ & $52.6 \%$ \\
\hline Only regular landline phone service & $52.1 \%$ & $46.6 \%$ & $51.6 \%$ & $47.5 \%$ \\
\hline Only cell phone service & $60.5 \%$ & $37.8 \%$ & $53.5 \%$ & $44.4 \%$ \\
\hline No telephone service at home & $61.1 \%$ & $36.2 \%$ & $58.8 \%$ & $39.5 \%$ \\
\hline
\end{tabular}

Sources - Election Day exit polls conducted by National Election Pool, Nov. 4, 2008 \& Nov. 2, 2004; Federal Elections Commission 


\section{The growing - and aging - cell-only voter population}

While much of the focus on cell-only voters remains on the youngest age groups ${ }^{4}$, where the incidence rates are very high, it is important to note that the majority of cell-only voters are ages 30 and older. This was true even in 2004, when $51.7 \%$ of cell-only voters in the NEP exit poll were 30 and up. Of course, part of this is simply the age composition of the voting public: the vast majority of voters are 30 or older - more than $80 \%$ in both 2004 and 2008. But in 2008 older voters made up a larger share of the cell-only population $-55.9 \%$ in the exit poll. The aging of the cell-only voter population is a consequence of the fact that the growth rate in cellonly status is even higher in older age groups than younger. This is most likely a result both of increasing adoption of cell phones by older people and of younger voters aging into older age groups and bringing their phone habits with them. NHIS data finds $21.6 \%$ of the $30-44$ age group was cell-only in the last half of 2008 (up from 19.1\% in the first half of the year), very close to NEP's estimate for this age group among voters (20.2\% cell-only).

Table 3 shows these differences in telephone service from 2004 to 2008 by age groups in the Election Day exit polls. Note that in this and following tables, the results for "Landline" voters collapses two categories in the exit poll question: "Both regular land-line and cell phone service" and "Only regular land-line phone service."

\footnotetext{
${ }^{4}$ In the newly released NHIS data for second half of 2008, a smaller proportion of all adults age 18-24 (33.1\%) are in wireless-only households compared to 18-24 voters in the Election Day exit poll (42.2\%). In the exit poll and in Pew's pre-election polling, cell-only 18- to 24-year-olds were more likely than their landline-reachable cohorts to be college graduates or have some college education. While these datasets lack all the necessary variables to draw firm conclusions, one possible explanation for this finding would be that the youngest cell-phone-only adults are more likely to vote than their cohorts with landlines. This may be related to a difference between young adults away at college and thus more likely to be wireless only compared to young cohorts who may still be living at home with parents and thus more likely to have landlines in the household. Another factor in the difference between the NHIS and NEP Election Day estimates may be differential distribution of cell-only 18- to 24-year-olds between the early voting and Election Day electorates.
} 
Table 3. Telephone Service by Age, 2004 and 2008

\begin{tabular}{lrrrrrrr}
\hline $\mathbf{2 0 0 8}$ & $18-24$ & $25-29$ & $30-39$ & $40-49$ & $50-64$ & $65+$ & Total \\
Landline & & & & & & & \\
Cell only & 51.7 & 51.8 & 72.2 & 81.4 & 87.4 & 91.1 & 76.0 \\
No phone & 42.2 & 40.8 & 23.2 & 14.8 & 9.7 & 7.4 & 19.9 \\
& 6.0 & 7.4 & 4.7 & 3.7 & 2.9 & 1.5 & 4.1 \\
$\mathbf{2 0 0 4}$ & 100.0 & 100.0 & 100.0 & 100.0 & 100.0 & 100.0 & 100.0 \\
Landline & & & & & & & \\
Cell only & 77.6 & 74.5 & 89.8 & 94.6 & 95.6 & 96.7 & 91.0 \\
No phone & 18.5 & 20.0 & 7.3 & 4.2 & 3.7 & 2.3 & 7.1 \\
& 3.8 & 5.5 & 2.9 & 1.2 & 0.7 & 1.1 & 2.0 \\
& 100.0 & 100.0 & 100.0 & 100.0 & 100.0 & 100.0 & 100.0 \\
Change in percent cell-only & & & & & & & \\
Pct increase on base & +23.7 & +20.8 & +15.9 & +10.6 & +6.0 & +5.1 & +12.8 \\
\hline
\end{tabular}

Source - Election Day exit polls conducted by National Election Pool, Nov. 4, 2008 \& Nov. 2, 2004.

The percentage of voters ages 30-39 who were cell-only more than tripled between 2004 and 2008, from $7.3 \%$ to $23.2 \%$. The growth rate among the $40-49$ age group was even greater, albeit on a smaller 2004 base, with the percentage cell-only increasing from $4.2 \%$ to $14.8 \%$. Significant increases also occurred among those 50 and older.

\section{Telephone status by other demographic and attitudinal variables}

Cell-phone-only status is also related to other key demographic correlates of electoral behavior. Table 4 provides a bivariate assessment of cell phone status in the 2008 Election Day exit poll sample by education, gender, race and income. Compared to the 2004 figures for these subgroups (Keeter 2006), the most sizable increases in cell-phone-only status occurred for low income and less educated voters. In 2004 some 13\% of Election Day voters with an annual income under $\$ 15,000$ were cell-only, and by 2008 that figure nearly tripled to $37 \%$. 
Table 4. What Type of Telephone Service Is There in Your Home That You Could Use or Be Reached On?

\begin{tabular}{|c|c|c|c|c|c|}
\hline & $\begin{array}{l}\text { Landline } \\
\text { Phone }\end{array}$ & $\begin{array}{l}\text { Cell Phone } \\
\text { Only }\end{array}$ & & $\begin{array}{c}\text { No Telephone } \\
\text { Service }\end{array}$ & $N$ \\
\hline Total & 76.0 & 19.9 & (1.4) & 4.1 & 7,341 \\
\hline Did not complete high school & 64.2 & 26.8 & (8.2) & 8.9 & 253 \\
\hline High school graduate & 73.7 & 21.1 & (3.2) & 5.2 & 1,382 \\
\hline Some college or associate degre & ee 73.9 & 22.5 & (2.5) & 3.6 & 2,327 \\
\hline College graduate & 76.7 & 19.1 & (2.6) & 4.2 & 1,936 \\
\hline Postgraduate study & 84.0 & 13.8 & (2.8) & 2.2 & 1,362 \\
\hline Male & 74.3 & 21.0 & (2.1) & 4.7 & 3,147 \\
\hline Female & 77.4 & 19.0 & $(1.8)$ & 3.6 & 4,155 \\
\hline White & 77.9 & 18.7 & (1.6) & 3.3 & 5,191 \\
\hline Black & 71.7 & 22.0 & (3.7) & 6.3 & 1,085 \\
\hline Hispanic/Latino & 67.2 & 27.6 & (5.4) & 5.2 & 587 \\
\hline Asian & 72.0 & 21.0 & (9.6) & 7.0 & 155 \\
\hline Other & 65.9 & 25.4 & (9.5) & 8.7 & 182 \\
\hline Under $\$ 15,000$ & 54.5 & 37.3 & (6.3) & 8.2 & 502 \\
\hline$\$ 15,000-\$ 29,999$ & 69.1 & 26.3 & (4.6) & 4.7 & 800 \\
\hline$\$ 30,000-\$ 49,999$ & 68.8 & 26.3 & (3.6) & 4.8 & 1,307 \\
\hline$\$ 50,000-\$ 74,999$ & 75.5 & 20.5 & (3.0) & 4.0 & 1,549 \\
\hline$\$ 75,000-\$ 99,999$ & 84.1 & 13.5 & (3.2) & 2.4 & 1,011 \\
\hline$\$ 100,000-\$ 149,999$ & 86.8 & 11.0 & (2.9) & 2.2 & 994 \\
\hline$\$ 150,000-\$ 199,999$ & 85.0 & 11.7 & (4.5) & 3.4 & 444 \\
\hline$\$ 200,000$ or more & 82.5 & 14.2 & (4.9) & 3.3 & 444 \\
\hline
\end{tabular}

Source - Election Day exit poll conducted by National Election Pool, November 4, 2008.

Note - Entries in parentheses are standard errors.

Table 5 provides a bivariate view of cell phone status by party identification, ideology and most important issue, followed by a multivariate view of those same cross-tabulations by age. The differences across telephone status within age groups are particularly informative because they indicate how well cell-phone-only voters are represented by their landline accessible peers. Several differences are apparent. Among older voters (age 30-39 and 40+), those living in landline households are more likely to consider themselves conservative than their cell-only peers. Among younger voters, by contrast, telephone status appears to be more closely related to party identification. Cell-only voters under age 30 are more likely to be Independents than their landline counterparts and perhaps less likely to be Democrats. 
Table 5. Party Identification, Ideology, and Issues by Telephone Service

\begin{tabular}{|c|c|c|c|c|}
\hline & Total & Landline & Cell Phone Only & No Telephone \\
\hline \multicolumn{5}{|l|}{ Total } \\
\hline \multicolumn{5}{|l|}{ Party Identification } \\
\hline Democrat & 41.9 & 41.0 & 44.4 & 47.1 \\
\hline Republican & 33.4 & 35.1 & 28.6 & 26.4 \\
\hline Independent & 20.8 & 20.8 & 21.4 & 18.9 \\
\hline Other & 3.8 & 3.1 & 5.6 & 7.5 \\
\hline \multicolumn{5}{|l|}{ Ideology } \\
\hline Liberal & 22.6 & 21.2 & 27.3 & 24.8 \\
\hline Moderate & 45.3 & 44.8 & 47.0 & 45.5 \\
\hline Conservative & 32.1 & 33.9 & 25.7 & 29.7 \\
\hline \multicolumn{5}{|l|}{ Most Important Issue } \\
\hline Energy policy & 7.5 & 7.1 & 8.5 & 9.4 \\
\hline The war in Iraq & 10.2 & 9.7 & 11.8 & 12.6 \\
\hline The economy & 65.0 & 65.5 & 65.4 & 54.3 \\
\hline Terrorism & 8.4 & 8.9 & 5.8 & 12.6 \\
\hline Health care & 8.8 & 8.8 & 8.5 & 11.2 \\
\hline Minimum sample size & $7,171(1.7)$ & $5,463(2.0)$ & $1,467(3.8)$ & $305(8.4)$ \\
\hline \multicolumn{5}{|l|}{ Age 18-29 } \\
\hline \multicolumn{5}{|l|}{ Party Identification } \\
\hline Democrat & 46.1 & 48.4 & 43.0 & 48.1 \\
\hline Republican & 27.1 & 27.9 & 26.5 & 24.7 \\
\hline Independent & 20.6 & 18.6 & 23.8 & 15.6 \\
\hline Other & 6.2 & 5.1 & 6.7 & 11.7 \\
\hline \multicolumn{5}{|l|}{ Ideology } \\
\hline Liberal & 32.7 & 32.7 & 32.2 & 36.0 \\
\hline Moderate & 43.6 & 43.6 & 43.6 & 42.7 \\
\hline Conservative & 23.7 & 23.7 & 24.2 & 21.3 \\
\hline \multicolumn{5}{|l|}{ Most Important Issue } \\
\hline Energy policy & 9.6 & 8.8 & 10.5 & 10.3 \\
\hline The war in Iraq & 13.3 & 13.7 & 13.1 & 11.5 \\
\hline The economy & 63.5 & 63.5 & 64.1 & 60.3 \\
\hline Terrorism & 4.7 & 4.8 & 4.1 & 7.7 \\
\hline Health care & 8.9 & 9.3 & 8.2 & 10.3 \\
\hline Minimum sample size & 1,617 (3.7) & $843(5.1)$ & $661(5.7)$ & $111(14.0)$ \\
\hline
\end{tabular}


Table 5. (Continued)

\begin{tabular}{lcccc}
\hline & Total & Landline & Cell Phone Only & No Telephone \\
\hline $\begin{array}{l}\text { Age 30-39 } \\
\text { Party Identification }\end{array}$ & & & & \\
$\quad$ Democrat & 40.6 & 39.2 & 45.0 & 40.0 \\
Republican & 33.9 & 36.0 & 28.3 & 30.0 \\
Independent & 21.1 & 20.6 & 21.9 & 26.0 \\
Other & 4.3 & 4.2 & 4.8 & 4.0 \\
Ideology & & & & \\
Liberal & 24.1 & 21.9 & 32.3 & 19.6 \\
Moderate & 44.4 & 44.3 & 43.5 & 51.0 \\
Conservative & 31.4 & 33.8 & 24.2 & 29.4 \\
Most Important Issue & & & & \\
Energy policy & 6.4 & 6.2 & 6.4 & 9.8 \\
The war in Iraq & 10.0 & 9.1 & 12.4 & 60.8 \\
The economy & 69.6 & 70.7 & 68.0 & 9.8 \\
Terrorism & 8.0 & 8.0 & 7.6 & 7.8 \\
Health care & 6.0 & 6.0 & 5.6 & $67(18.0)$ \\
Minimum sample size & $1,485(3.8)$ & $1,062(4.5)$ & $347(7.9)$ &
\end{tabular}

\section{Age 40+}

Party Identification

\begin{tabular}{lcccc} 
Democrat & 40.8 & 39.9 & 45.5 & 49.5 \\
Republican & 35.6 & 36.4 & 32.0 & 26.8 \\
Independent & 20.8 & 21.3 & 17.9 & 17.5 \\
Other & 2.8 & 2.4 & 4.6 & 6.2 \\
Ideology & & & & \\
Liberal & 18.5 & 18.6 & 17.3 & 18.9 \\
Moderate & 46.1 & 45.2 & 53.6 & 44.2 \\
Conservative & 35.4 & 36.1 & 29.1 & 36.8 \\
Most Important Issue & & & & \\
Energy policy & 7.1 & 7.0 & 7.7 & 13.8 \\
The war in Iraq & 9.2 & 9.0 & 9.6 & 45.7 \\
The economy & 64.0 & 64.5 & 65.2 & 18.1 \\
Terrorism & 10.0 & 10.1 & 6.8 & 13.8 \\
Health care & 9.7 & 9.4 & 10.7 & $122(13.3)$ \\
Minimum sample size & $4,054(2.3)$ & $3,475(2.5)$ & $456(6.9)$ & \\
\hline
\end{tabular}

Source - Election Day exit poll conducetd by National Election Pool, November 4, 2008.

Note - Entries in paren theses are standard errors for statistics with response distribution of $50 \%-50 \%$. 
There also were differences by phone status in voter mobilization. Cell-only voters were far more likely than those with landlines to have voted for first time in 2008, though naturally this correlates strongly with age (youngest voters most likely to be cell-only and also most likely to be new voters). But cell-only Election Day voters were far less likely to have been contacted by either campaign. Even Obama's campaign - renowned for its technological innovation, including its plan to use text messaging to notify 3 million supporters of Obama's vice-presidential pick was more likely to contact landline-reachable than cell-only voters, according to the Election Day exit poll. (So it's not only pollsters who have trouble reaching those who are wireless-only.)

Some attitudinal variables produced no significant differences between cell-only and landlinereachable voters, such as whether the candidates' race or age were factors in voting for president. Measures of the economy produced mixed results: no significant difference in likelihood of calling the economy the nation's most important issue nor in worry about the economy's direction over the next year, but cell-only Election Day voters were a little more likely than the landline-reachable to say the economy currently was poor. Significant differences by telephone status appeared in other variables, often those related to partisanship or ideology; for example, cell-only respondents were a little more "excited" about an Obama presidency and 10 points more likely than landline-reachable voters to strongly disapprove of George W. Bush’s performance as president. These results suggest it may not be easy to predict how cell phone non-coverage bias may affect individual estimates within a survey.

\section{Presidential voting by age and phone status}

Perhaps the most striking finding of the 2008 exit poll question on telephone status was how differences in voting patterns between cell-phone-only and landline-reachable respondents played out among age groups.

Differences in presidential vote between the landline and cell-only groups in 2008 were largest among voters ages $30-39$. Obama was the choice of $62.6 \%$ of cell-only voters ages $30-39$ but only $51.3 \%$ among those reachable by landline, a difference of 11.3 percentage points. The difference was smaller among all other age groups in the survey: 7.9 points among those 40-49, 7.4 points among those $18-24$, and much less among those $25-29$ and $50+$.

In 2004 cell-only voters older than 29 were such a small part of the voting population that their voting patterns, however different, posed little risk of biasing election surveys based on landline samples. In fact, older cell-only voters in 2004 differed a little more from their landline counterparts than younger ones did. This age difference grew in 2008. Compared with older landline voters, older cell-only voters were more Democratic in their vote patterns than they had been in 2004. Coupled with the fact that far more voters in both age groups were cell-only in 2008, the potential for bias in landline surveys was also higher. 
Table 6 presents Election Day exit poll data on vote by age and telephone status in 2008 and 2004. Among all voters 30 and older, Obama was the choice of 55.5\% of those who were cellonly and $47.8 \%$ of the landline-accessible, a difference of 7.7 percentage points. Among voters 18-29, the difference was 4.9 points. Four years earlier, the difference among the 30+ age group was 2.8 points; among those $18-29$ it was 2.2 points. Thus, the disjuncture between landline and cell-only voters grew more among older voters than among younger ones.

Table 6. Presidential Vote by Telephone Service

\begin{tabular}{|c|c|c|c|c|c|c|c|c|c|c|}
\hline \multicolumn{2}{|c|}{2008} & \multirow{2}{*}{$\begin{array}{r}\text { Landline } \\
61.2\end{array}$} & \multirow{2}{*}{$\begin{array}{r}\text { Cell only } \\
68.6\end{array}$} & \multirow{2}{*}{$\frac{\text { Diff. }}{-7.4}$} & \multicolumn{2}{|c|}{2004} & \multirow{2}{*}{$\begin{array}{r}\text { Landline } \\
59.5\end{array}$} & \multirow{2}{*}{$\begin{array}{r}\text { Cell only } \\
62.5\end{array}$} & \multicolumn{2}{|c|}{ Diff Diff of diffs } \\
\hline $18-24$ & Obama & & & & $18-24$ & Kerry & & & -3.0 & 4.4 \\
\hline & McCain & 36.8 & 29.3 & 7.5 & & Bush & 39.3 & 36.5 & 2.8 & 4.7 \\
\hline & Other & 2.1 & 2.1 & & & Other & 1.2 & 1.0 & & \\
\hline & & 100.0 & 100.0 & & & & 100.0 & 100.0 & & \\
\hline \multirow[t]{4}{*}{$25-29$} & Obama & 63.3 & 65.4 & -2.1 & $25-29$ & Kerry & 51.5 & 53.4 & -1.9 & 0.2 \\
\hline & McCain & 35.6 & 33.6 & 1.9 & & Bush & 46.6 & 45.5 & 1.2 & 0.7 \\
\hline & Other & 1.1 & 0.9 & & & Other & 1.8 & 1.1 & & \\
\hline & & 100.0 & 100.0 & & & & 100.0 & 100.0 & & \\
\hline \multirow[t]{4}{*}{$30-39$} & Obama & 51.3 & 62.6 & -11.3 & $30-39$ & Kerry & 46.9 & 49.3 & -2.5 & 8.9 \\
\hline & McCain & 47.1 & 36.2 & 10.9 & & Bush & 52.3 & 48.0 & 4.3 & 6.6 \\
\hline & Other & 1.6 & 1.2 & & & Other & 0.9 & 2.7 & & \\
\hline & & 100.0 & 100.0 & & & & 100.0 & 100.0 & & \\
\hline \multirow[t]{4}{*}{$40-49$} & Obama & 46.6 & 54.5 & -7.9 & & & & & & \\
\hline & McCain & 51.2 & 44.3 & 6.9 & & & & & & \\
\hline & Other & 2.2 & 1.1 & & & & & & & \\
\hline & & 100.0 & 100.0 & & & & & & & \\
\hline \multirow[t]{4}{*}{$50+$} & Obama & 46.9 & 46.8 & 0.1 & & & & & & \\
\hline & McCain & 52.2 & 52.1 & 0.1 & & & & & & \\
\hline & Other & 0.9 & 1.1 & & & & & & & \\
\hline & & 100.0 & 100.0 & & & & & & & \\
\hline
\end{tabular}

Source - Election Day exit polls conducted by National Election Pool, Nov. 4, 2008 \& Nov. 2, 2004

\section{Possible reasons for political differences between cell-only and landline-accessible voters}

The political differences between the cell-only and landline-accessible voters - which include presidential vote but also party affiliation and ideology - likely stem from the life-cycle and socio-economic differences between these two groups which were described earlier and are 
correlated with political views. For example, income differences, as shown in Table 7, are sizeable among all age groups but especially so among voters ages 30-49.

Table 7. Family Income by Age and Phone Status

\begin{tabular}{|c|c|c|c|c|c|}
\hline & & Landline & Cell only & Total & Diff \\
\hline \multirow[t]{4}{*}{$18-24$} & $<\$ 50,000$ & 51.7 & 62.7 & 57.1 & -11.0 \\
\hline & $\$ 50,000-\$ 100,000$ & 28.8 & 24.6 & 26.6 & 4.2 \\
\hline & $\$ 100,000+$ & 19.5 & 12.7 & 16.4 & 6.8 \\
\hline & & 100.0 & 100.0 & 100.0 & \\
\hline \multirow[t]{4}{*}{$25-29$} & $<\$ 50,000$ & 49.1 & 55.5 & 52.5 & -6.4 \\
\hline & $\$ 50,000-\$ 100,000$ & 36.6 & 32.2 & 34.6 & 4.4 \\
\hline & $\$ 100,000+$ & 14.3 & 12.3 & 12.9 & 2.0 \\
\hline & & 100.0 & 100.0 & 100.0 & \\
\hline \multirow[t]{4}{*}{$30-39$} & $<\$ 50,000$ & 27.7 & 47.2 & 32.8 & -19.5 \\
\hline & $\$ 50,000-\$ 100,000$ & 44.2 & 34.0 & 41.5 & 10.2 \\
\hline & $\$ 100,000+$ & 28.1 & 18.8 & 25.7 & 9.3 \\
\hline & & 100.0 & 100.0 & 100.0 & \\
\hline \multirow[t]{4}{*}{$40-49$} & $<\$ 50,000$ & 25.0 & 50.3 & 29.0 & -25.3 \\
\hline & $\$ 50,000-\$ 100,000$ & 36.9 & 31.2 & 36.1 & 5.7 \\
\hline & $\$ 100,000+$ & 38.1 & 18.5 & 34.9 & 19.6 \\
\hline & & 100.0 & 100.0 & 100.0 & \\
\hline \multirow[t]{4}{*}{$50+$} & $<\$ 50,000$ & 33.2 & 44.1 & 34.9 & -10.9 \\
\hline & $\$ 50,000-\$ 100,000$ & 38.3 & 41.4 & 38.3 & -3.1 \\
\hline & $\$ 100,000+$ & 28.5 & 14.5 & 26.8 & 14.0 \\
\hline & & 100.0 & 100.0 & 100.0 & \\
\hline
\end{tabular}

Source - Election Day exit poll conducted by National Election Pool, Nov. 4, 2008.

Unfortunately, other important variables related to phone status and the vote were not asked on the same forms of the questionnaire that included phone status, including marital status and presence of children in the home. Religion, which is associated with social integration and is correlated with phone status, also was not asked on the same forms. Homeownership - with renting known to be a strong predictor of cell-only status - was not asked in the exit poll at all.

Perhaps as a consequence, it is difficult to identify the most important drivers of the coverage bias in estimating the vote. A multivariate regression analysis predicting the vote finds that including the available demographic variables - age, sex, education, income and race - reduces the impact of telephone status somewhat but leaves much of the variability unexplained. The gap in predicted probability of a vote for Obama between cell-only and landline-accessible voters, 
without controlling for demographic characteristics, is 10.7 percentage points. Including the demographics in the model reduces this difference to 6.7 points.

\section{Meta-analysis of Dual- versus Single-frame 2008 Pre-election Polls}

To help weigh implications of the findings above for RDD surveys in the future, we now turn to an evaluation of the accuracy of the final 2008 pre-election polls, some of which excluded cellphone-only respondents.

We conducted a meta-analysis of 19 national polls conducted during the final week of the 2008 presidential campaign, of which 17 were telephone polls and two were non-probability Web surveys completed by opt-in panel members. Among polls conducted by telephone, seven used a dual-frame design and 10 used only a landline sample. All the polls projected the correct winner, but given Obama's 7-point victory margin, this is perhaps to be expected. To gauge the relative performance of the polls, we computed the $A$ value for each (Martin, Traugott and Kennedy 2005). The measure $A$ summarizes the degree to which the poll estimate of the relative vote share of the top two candidates deviated from the election result. $A$ values closer to zero reflect greater accuracy than those farther from zero in either direction. Values with a positive sign reflect overestimation of support for Obama (and underestimation of support for McCain) relative to the outcome. Negative values reflect overestimation of support for McCain (and underestimation of support for Obama). The results are presented in Table 8. Several of the polls (six of 19) allocated the percentage of undecided voters to the candidates in their final estimates. $A$ is not altered if the undecided voters are dropped, allocated proportionally, or kept as undecided. 
Table 8. Accuracy of Pre-Election Polls by Sample Design

\author{
Election Result \\ FOX News/Opinion Dynamics \\ Ipsos McClatchy \\ CNN/Opinion Research Corp. \\ American Research Group \\ IBD/TIPP \\ Harris Interactive \\ YouGov/Polimetrix \\ Pew Research Center \\ Rasmussen \\ NBC News/Wall Street Journal \\ George Wash. U. \\ (Lake/Tarrance) \\ ABC News/Washington Post \\ GQR/Democracy Corps* \\ Diageo/Hotline \\ Research 2000 \\ Marist College \\ CBS News/New York Times \\ Gallup \\ Zogby
}

\section{Mean $A^{* *}$ \\ Dual frame RDD polls \\ Landline RDD polls}

*The GQR final poll was a landline RDD sample, but "because of a small actual sample of younger voters under 30 years and because all were on landlines producing a much more conservative-leaning youth sample, we substituted this data for our younger voter survey which used a multi-modal approach to reach younger voters through landlines, web survey and cell phones."

** Mean of absolute values of $A$

Landline polls and dual-frame polls differed little in accuracy by this measure. The mean of the absolute values of $A$ was 0.03 for the landline RDD polls versus 0.04 for the dual-frame polls. Two polls, Reuters/CSPAN/Zogby (landline only) and Gallup (dual-frame), estimated Obama would win by 11 percentage points compared to the actual 7-point margin; when those polls are
0.04

0.03 
excluded, the average absolute $A$ values for the landline and dual-frame groups of polls are equivalent (0.03).

While the accuracy of single- and dual-frame RDD polls was comparable, there is some evidence that the direction of deviations from the election outcome differed by design. The three polls understating Obama's relative vote share the most (Research 2000, Diageo/Hotline, George Washington University/Lake/Tarrance), as indicated by the negative $A$ values, all excluded cell phone numbers. The direction of this result is consistent with earlier evidence in this election cycle that support for the Democratic candidate was greater in surveys that included cell phones. In the 2008 contest, however, post-survey adjustments were still sufficient to keep the accuracy of landline sample designs on par with that of dual frame designs in estimating the size of Obama’s victory margin.

\section{Conclusions}

The growth in wireless substitution in the United States since 2004 as evidenced by the household telephone status question on the NEP national exit polls confirms the pattern seen in government surveys: Future RDD surveys are likely to be subject to larger non-coverage bias if they exclude respondents who only may be reached on cell phones. Multiple pre-election polls in 2008 provide additional support for this conclusion; including cell-only voters tended to increase the estimates of preference for Barack Obama by 2 to 3 percentage points. Fortunately, even the final pre-election surveys that excluded cell-only voters performed on a par with RDD polls that included a cell sample when the measure of accuracy is the difference in support for Obama and McCain.

Cell-phone-only incidence now is about $20 \%$ of all households in the United States, up from $7 \%$ four years ago, and the rate of growth shows no sign of slowing. We see no evidence in the available data that non-coverage bias from excluding cell-only respondents might diminish rather than grow in the coming years.

Many differences between cell-only and landline-reachable respondents are well documented, including the fact that people who have only cell phones tend to be younger, less affluent, single, and renters rather than homeowners. But the 2008 exit poll produced some surprises, most notably that the difference in presidential vote preference was even greater among older voters than for younger voters. As a result of this change, weighting adjustments for age alone are less likely to correct for non-coverage bias since the behavior of landline and cell-only respondents within a homogeneous age group is less similar than it was four years ago.

Finally, the large number of voters casting ballots before Election Day means that any effort to provide a definitive accounting of voter attitudes and behavior through an exit poll process should be accompanied by data collection among early voters that includes the cell-only population. The same is true for pre-election telephone surveys. 


\section{References}

American Association for Public Opinion Research. 2008. "Guidelines and Considerations for Survey Researchers When Planning and Conducting RDD and Other Telephone Surveys in the U.S. With Respondents Reached via Cell Phone Numbers.” Available from: http://www.aapor.org/uploads/Final_AAPOR_Cell_Phone_TF_report_041208.pdf. Accessed May 19, 2009.

Associated Press Election Research. 2009. “2008 Turnout and Advance Voting.” Unpublished report dated April 21, 2009. Cited by permission.

Benford, Robert, Trevor Tompson, Barry Feinberg, Geoff Feinberg, Annie Weber, Nicole Speulda and Christopher Fleury. 2009. "Wireless and Wireline: Dual Frame Implications for Sample Design Decisions on Estimates, Weighting and Costs.” Paper presented at the $64^{\text {th }}$ Annual Conference of the American Association for Public Opinion Research, Hollywood, Fla., May 2009.

Blumberg, Stephen J. and Julian V. Luke. 2009. "Wireless substitution: Early release of estimates from the National Health Interview Survey, July-December 2008.” National Center for Health Statistics. Available from: http://www.cdc.gov/nchs/nhis.htm. Accessed May 6, 2009.

Fahimi, Mansour, Dale Kulp and J. Michael Brick. 2008. "Bias in List-Assisted 100-Series RDD Sampling.” Survey Practice, September 28, 2008.

Keeter, Scott. 2006. "The Impact of Cell Phone Noncoverage on Polling in the 2004 Presidential Election." Public Opinion Quarterly 70:88-98.

Keeter, Scott, Courtney Kennedy, April Clark, Trevor Tompson, and Mike Mokrzycki. 2007. "What's Missing from National Landline RDD Surveys? The Impact of the Growing Cell-Only Population,” Public Opinion Quarterly 71: 772-792.

Keeter, Scott, Michael Dimock and Leah Christian. Sept. 23, 2008. Cell Phones and the 2008 Vote: An Update. Pew Research Center for the People \& the Press. Available from: http://pewresearch.org/pubs/964/. Accessed May 22, 2009.

Keeter, Scott, Michael Dimock and Leah Christian. Dec. 18, 2008. Calling Cell Phones In '08 Pre-Election Polls. Pew Research Center for the People \& the Press. Available from: http://people-press.org/reports/pdf/cell-phone-commentary.pdf. Accessed May 22, 2009.

Langer, Gary, Peyton Craighill, Patrick Moynihan, Jon Cohen, Jennifer Agiesta and Dave Lambert. 2009. “These Nutty Pollsters’: Methodological Issues in ABC News/Washington Post 2008 Pre-Election Polling.” Paper presented at the $64^{\text {th }}$ Annual Conference of the American Association for Public Opinion Research, Hollywood, Fla., May 2009.

Martin, Elizabeth A., Michael W. Traugott, and Courtney Kennedy. 2005. “A Review and Proposal for a New Measure of Poll Accuracy.” Public Opinion Quarterly 69: 342-367. 
National Election Pool, Edison Media Research, and Mitosky International. 2005. National Election Pool General Election Exit Polls, 2004 [Computer file]. ICPSR version. Somerville, NJ: Edison Media Research/New York, NY: Mitofsky International [producers], 2004. Ann Arbor, MI: Inter-university Consortium for Political and Social Research [distributor]. 